\title{
THE USES OF TERROR AND THE LIMITS OF CULTURAL STUDIES
}

\begin{abstract}
The plot of the event of September 11 - the destruction of the twin towers of the World Trade Center by terrorists - might have been written by Hollywood, or by Baudrillard. So fantasmatic, so familiar was the scenario that it fitted seamlessly into the manichaean agenda of the Pentagon hawks planning the next American war, and the next. Indeed, a perfectly plausible paranoid response reads this plot as a plot on the part of those who have most thoroughly benefited from it. How do we take fantasms seriously when they come true?
\end{abstract}

The word 'case' names the genre of legal, medical or moral story in which the singularity of the story-incident is set in relation to a general principle which in some sense informs it or can be derived from it. Jolles (1930), defining the casus as one of nine 'simple forms' of discourse, sees its characteristic structure as the problematisation of the normative scheme it instantiates. Unlike the example, it is anomalous with respect to that scheme and gives rise to a set of questions about it. It thereby mediates between the contingency of its occasion and the generality of a principle, and initiates procedures for weighing the one against the other. In the legal case, this involves a dialectic between the code of the law (or the sedimented code read from precedent cases which have themselves become a form of law) and the exceptional circumstances (and they are always exceptional) shaping this particular story (Gadamer, 1998: 325-30, 518-21). The medical case, or case history, similarly sets the complexity and thus the partial inscrutability of the body or the life against the abstract scientific principles governing bodies or psyches in general. The tradition of the moral case study developed in jesuitical casuistry is concerned with the application of ethical principle to the complexity of human circumstance: it is a morality of the exceptional and its relation to the norm (Jonsen and Toulmin, 1988).

James Chandler's rigorous analysis of the genre makes it clear that the case is always a matter both of particularity and of generality. To say that ' $\mathrm{x}$ is a case (or instance) of y' is to point to the relation of instantiation itself and thus to the problem of the representativity of the case insofar as it is a case of something else (Chandler, 1998: 200, n. 85). In the same vein, Burke (1962) speaks of the case as a 'representative anecdote' which acts (as it does somewhat later in Kuhn's (1996) account of the shaping of scientific agendas) as an epistemological 'paradigm' or 'prototype'. Burke's interest is methodological: every scientific or philosophical vocabulary, he writes, is built around such representative cases which shape what can be known in a particular field because the case: 
contains in nuce the terminological structure that is evolved in conformity with it. Such a terminology is a 'conclusion' that follows from the selection of a given anecdote. Thus the anecdote is in a sense a summation, containing implicitly what the system that is developed from it contains explicitly. (Burke, 1962: 60; on the sociological case study, cf. Ragin and Becker, 1992)

Such prototypical modelling, which Kuhn (1996) describes as the normal mode of operation of protocols of knowledge in the sciences, is at once a strength and a weakness of every organised discipline of knowledge: if the field of the knowable is structured by certain exemplary cases, the form that they take generates a model of typicality which may or may not fit every particular case within that field.

But if the case may implicate an epistemological or moral generality, its structure of representativeness may also have a historical force. This is Chandler's argument concerning Romantic historicism: that the historical typicality of the case 'involves the identification of cultural conjuncture in terms of the chronological code' (and gives rise to the concept of the 'historical situation') (Chandler, 1998: 228). However specific and detailed the description of this situation may be, it is organised in some sense as the totalising principle of an epochal Zeitgeist, in which every local story is a moment - at once an aspect and a condensed reflection - of a larger structure of meaning. In this paper I use the concept of the casus in this sense to refer to a story or a story-image which works with overwhelming power to crystallise an explanation of what the world is historically like, but also - and here I draw on Jolles' (1930) description — to problematise the normative schema from which it arises.

The historical casus has the form of an event in which a rupture opens in the fabric of historical time: first there was a kingdom, and then the king's head was cut off. At the same time, it tends to condense its narrative sequence into a visual schema with emblematic force (the scene of the scaffold, for example). Any such story may assume different degrees of specificity, and may be more or less universal in its implications: 'Vietnam' was a casus, but so were the images of a napalmed child or an executed Viet Cong prisoner, and these more specific eventpieces work to reduce a complex narrative to a humanly graspable scale. The casus may be a national or global event (the sinking of the Titanic, the O.J. Simpson trial, the assassinations of John Kennedy or Martin Luther King) or a matter of very local reach (an act of violence in one's neighbourhood). At its most powerful, it imposes an interpretation (or rather a field of interpretation) of history on a whole generation: the French Revolution, the uprisings of 1848 , World War I all turn the sense of history's direction away from its expected course and pattern it in accordance with a new set of questions, a new agenda. They inflect history (to borrow a term from the lexicon of grammatical case). The Cold War was crucially shaped by exemplary stories like Nixon's discovery of stolen nuclear secrets in a pumpkin, or Kennedy's facing off of the Soviet Union in the missile crisis, or in Australia by the Petrov affair. The representative anecdote that is the casus is in each ease always contested, because it is at the heart of the engagement of political forces: Burke and Paine make very different kinds of ethicopolitical sense of the French Revolution, but the shape of the casus guides interpretation, 
sets limits to what sense can be made of it. There is no European politics over a period of 15 years that is not directly a function of the image of the French Revolution, and there is no politics in the entire nineteenth century which does not in some sense refer to the twin themes of the Revolution and the Napoleonic hegemony.

Hegelian Marxists would read the casus as a structure of typicality, a crystallisation of historical trends (cf. in particular Lukács, 1969). For Lukács, it would exemplify the narrative category of Besonderheit, particularity, which mediates between typicality and generality and which catches the directionality of historical time. We, by contrast, might well be struck by the apparent randomness with which such stories erupt and take hold, and the way the course of history is thus pushed in unpredictable directions: the fall of the Berlin Wall is precisely such a moment, an event which seems entirely necessary in retrospect yet which at the time took everybody, not least the protagonists, by surprise. Etymologically, the word casus (like the German Fall) means a falling or a befalling, and it is cognate with the occasion, the contingent structure of the way the world is; the casus is or appears to be a matter of chance (although it also generates its own causality and its own generality) (Derrida, 1984). The event of 11 September 2001 (henceforth 9/11, the hieroglyph condensing 'cultural conjuncture' into 'chronological code') is in this sense a befalling, an incident without apparent precedent or cause, an anomaly which nevertheless generates new principles, new understandings, new historical generalisations. It carries embedded within it the principles of a change in the course of history, and these principles flow with apparent necessity from the images that constitute the event. Although one possible reading of $9 / 11$ would involve finding in it a confirmation of the wrongs of US foreign policy, particularly in the Middle East, its immediate and contrary narrative message is something like: evil people are intent on destroying us. At a higher level of generality, and however bizarre it may seem, it proclaims that world history should be read as the history of a struggle between Islam and Christendom, a reading which is then reinforced by the neo-Hegelian discourses of the historicist American right. Storyshaped, the event exemplifies this interpretation, with all the consequences that then derive from it.

These messages are, of course, in no way immediate. They were prepared by years of ideological work which created a ready-made explanatory framework, and this is a major part of the point about how the casus functions: that apparently random shifts in historical awareness, in the direction and shape of history, are always the result of intense collective effort, or rather of the collision and interaction of contradictory efforts. We should note in particular the determination and efficiency with which the United States Right, during and beyond the Reagan era - preempting the left's Gramscian doctrine of the long march through the institutions used the resources of well-funded policy institutes and of targeted placements in the bureaucracy to consolidate a massive shift in ideological hegemony which spread well beyond the political establishment to the broad mass of popular culture (Blumenthal, 1986). In this case, the casus of $9 / 11$ crystallises a set of pre-existing cultural tropes about the relation to otherness. Zizek thus describes the ways in 
which the 'terrorist threat' was already libidinally invested in a series of movies from Escape From New York to Independence Day in such a way that 'the space for it was already prepared in ideological fantasizing'; and he wams that 'it is precisely now, when we are dealing with the raw Real of a catastrophe, that we should bear in mind the ideological and fantasmatic coordinates which determine its perception' (Zizek, n.d.).

The event of $9 / 11$ worked so powerfully because it was an extraordinary an exemplary - piece of symbolism. Remember that essay of Baudrillard's in which he asks why there are two towers in the World Trade Center rather than one, and answers in terms of the difference between the singular reality which characterises a mode of production and the specular structure characteristic of a mode of simulation (Baudrillard, 1993: 69). The towers, in their smooth lack of figuration, their pure and abstract geometricality, are the great architectural icons of non-representation, blankly reflecting nothing other than themselves, stripped of all reference to a world beyond them. The themes of the event of $9 / 11$ are the classic ones of Baudrillard's meditations on postmodernity: terrorism as the archetypal liquidation of meaning, the twin towers as the essence, in their specular doubleness, of the realm of simulation, the catastrophic event as an implosion of meaning; indeed, the implosion of the towers repeated precisely, but as an effect of random violence -- what Jencks (1987) calls the defining moment of postmodemity - the controlled implosion in 1972 and 1973 of the Pruitt-Igoe tower project in St Louis. These themes merged in the $9 / 11$ script with the Hollywood tropes of the towering inferno and the criminal mastermind striking from his remote stronghold against the vulnerable heart of Western civilisation. The Bush administration's response, in turn, played to the same script, mobilising the forces of good against the forces of darkness, leading a 'crusade' against an enemy defined both as the shadowy master criminal and an equally shadowy axis of evil; and these themes, this fully familiar iconography, were accompanied by a secondary iconography: the heroic firefighter, the sleeper cells embedded deep within the polis. Beyond all this, the script reinforced the universal sense that America - the name by which the United States conceals its domination of the Americas - is in some world-historical sense exemplary, that 'America' is in and of itself a poetic theme, that the tragic destiny of 'America' carries a significance that Rwanda, say, or Bosnia, or Bangladesh do not. Yet this thematics of historical destiny too is intertwined with and mirrors its other. The iconoclasm which was so central a dimension of the destruction of the World Trade Center towers is already implicit in the towers' astonishingly specular anti-representationality, and mirrors an iconoclasm rooted deep in the puritan and prohibitionist face of US culture, a face perhaps most recently expressed in its army's complicit tolerance of the desecration of the Baghdad Museum.

Faced with these scenarios we become cultural critics, interrogating the ideological force of this script, puzzling over its incoherences. Every casus is contested, especially when we are so aware of the ways in which earlier exemplary stories - Nixon's pumpkin, the Tonkin Gulf incident - were fabricated for political uses. Inevitably, then, counter-scenarios were proposed. Various versions of a conspiracy 
theory have circulated widely in cyberspace, marshalling detailed interrogations of fact. Here I want to look more closely at one of them - an essay by Gore Vidal entitled 'The Enemy Within' (Vidal, 2002) - in order to think a little more about the form of rationality embedded in the casus, about its constructedness as a nodal point of historical significance, and about what might constitute an appropriate response to it.

Vidal follows three main lines of questioning. In the first, $9 / 11$ is read as a rationalisation for a war which had already been prepared: 'Osama was chosen on aesthetic grounds to be the frightening logo for our long-contemplated invasion and conquest of Afghanistan.' The structure of interest underlying this invasion had to do with control of Caspian oil and gas, and in particular the pipeline which Union Oil of California had sought in the early 1990s to build from Turkmenistan through Afghanistan to the Pakistani port of Karachi - a proposal which had been blocked by the Taliban, and which is now going ahead following the appointment of a Unocal employee as the US envoy to Afghanistan, and the installation of a former employee of a Unocal subsidiary as president of Afghanistan. In this context, it is almost superfluous to point to the close ties binding the two Bush administrations to the oil industry.

In a second strand, Vidal focuses on the suspension of normal interception operations during the 9/11 attack. The standard order of procedure in the event of a hijacking is for fighter planes to be sent up to explore why a plane has deviated from its flight path. This did not happen on September 11, and the president, who has the sole authority to authorise a plane to be shot down, was not notified until much later in the morning. Whereas by law the fighters should have been in the air by about 8.15 a.m., in the event aircraft were ordered up only at 9.40 a.m., 'one hour and 20 minutes after the air controllers knew that Flight 11 had been hijacked; 50 minutes after the North Tower was struck'. No one has been held accountable for this lapse, and the investigation into procedures was held secretly and with a limited brief, 'in the interests of security'. Vidal draws from this the conclusion that the Air Force must have been ordered to abstain from protective action, and this in turn implies the complicity of the Bush administration in the attacks.

The third line of analysis is logistical: Vidal cites the former Egyptian foreign minister Mohammed Heikal as saying that $\mathrm{Al}$ Qaeda had been under intensive surveillance for years by US, Pakistani, Saudi, Israeli and Egyptian intelligence organisations, with every phone call being monitored. 'They could not,' he says, 'have kept secret an operation that required such a degree of organisation and sophistication.' Vidal draws from this the conclusion that only a state or a state apparatus had the logistical sophistication to plan and launch the attacks, and he proposes various candidates - including Israel, the United States itself, or Pakistan's Inter Services Intelligence which, with US aid, trained and coordinated radical Muslim groups in Afghanistan from 1985 onwards.

Vidal draws no final conclusions from his argument, although there is no shortage of candidates in the literature circulating on the web. But only two conclusions are conceivable: either the Bush administration was complicit in the attacks, as indicated by the standing down of intercepting aircraft; or it was not, but used the occasion opportunistically to harvest a series of economic and political benefits. 
The standard line in the theorisation of conspiracy, as indeed in any criminal investigation, is to ask who benefits. The answer to this question in the case of 9/11 identifies three major benefits: first, the opening up of Caspian oil to US companies; second, the accrual of extensive war powers to the president, with the longer term prospect of linking Iraq to the master criminal and so of legitimating a war that would similarly open up Iraqi oil reserves to the United States and then, in some eyes, permit further extensions of American power by military means; and third, the accrual of extensive powers of surveillance and control within the national polity. In most countries of the Western world, something like a permanent state of emergency has been embedded in the legislation that responds to the ill-defined and in principle endiess 'war on terror' by removing a range of basic civil liberties.

There is no doubt that $9 / 11$ has been a gift to the Right. It has legitimated a strengthening of the powers of the state against its citizens, and an extension of American military power in what has become a more overtly imperialist defence of US interests. When George Bush continues to define the invasion of Iraq, despite the overwhelming lack of evidence of any connection between the Iraqi state and Al Qaeda, as a moment in a global war on terror, and when Donald Rumsfeld tells US troops of the need to continue 'to root out the terrorist networks operating in this country' - networks which, as Fisk (2003) argues, may not yet exist but certainly will come into being as the Shia Muslim community begins to resist American occupation - then the rhetoric of democracy and liberation begins to look very much like the lies with which every war of aggression is justified.

Yet there are obvious problems with conspiracy theories such as that of Vidal. On the one hand, they produce a multiplication of facts in such a way that every detail becomes imbued with significance. On the other, there is a multiplication of stories to the point where the excess of significance undermines narrative coherence. The theory of the administration's complicity in the attacks provides no plausible chain of agency leading from the White House to the hijackers; the opportunism theory can't make sense of the apparent order not to intercept the hijacked planes. Such theories are a form of paranoid interpretation (which is not to say they may not be, in part or in whole, true), and the form they take is that of a hyperrationalism which assumes that the world has an underlying order which can be made transparent to investigative scrutiny.

What form of rationality might be appropriate, then, to the analysis of the fantasmatic event? What is at issue here is of course a politics of representation - and (apart from the truistic sense in which all politics is representational) it is crucial to remember that this is only one of the political dimensions of the casus of 9/11: it brought about one war and was then used in partial justification of another; it has restructured relations between the West and lslam, and has helped both to impose a factitious unity upon those terms and to imbue the secular categories of Western political discourse with a set of charged religious overtones. But insofar as it has also been drawn into an ongoing cultural politics, this has been, inter alia, through its mobilisation as an epistemological weapon against any form of social constructionism: it figures as something like a bedrock of fact, the materialisation of those fantasms that have haunted our culture in the form of the 
alien other, the purely evil Will standing outside the human pale and emblemising all that threatens us. With the passing of the Cold War, a new outside is created for our life which authorises every form of Realpolitik. Yet it is just because this brute reality lends itself so readily to ideological purposes that we should attend to Zizek's call to take note of the 'fantasmatic coordinates' through which it is made comprehensible to us, and through which it is constructed as a brute reality. In methodological terms, a reading of the fantasmatic reality of public events and of what Laplanche and Pontalis (1973: 315) call the psychic reality of the fantasm should then mean the abandonment of any simple distinction between textual study and empirical analysis: empirical facts are textually, discursively, ideologically built; texts such as that of the casus are themselves real and are bound up with real structures of enunciative interest.

A politics of representation is at once a politics of the anecdote and the image, and of the laborious struggle over meaning that prepares the ground for anecdotes and images to 'work'; it assumes the power of the media, especially television, to shape the casus, but it must also assume the power of the institutions of the public and counter-public spheres to shape or modify the course of media representation. The casus must be understood as a construct, though not necessarily as a fabrication in the sense Vidal construes it to be one. To refer to the public sphere, however, is perhaps to suppose a form of reasoned argument which may well miss the force of the emblematic rationality of the casus, its condensation of a historical logic into a rhetoric of figure and implication. Figures can be unpacked, stories can be denarrativised by translation into propositional form; but any gain in explicitness is offset by a loss of rhetorical force. In a complementary operation, emblems can be appropriated and turned from the matrix of implications in which they are framed. Each of these operations is central to a counter-politics of representation, and each has a limited power; together, they indicate something of the limits, but also of the potential, of a politically engaged cultural studies.

\section{Notes}

1 An earlier version of this paper was given at the annual conference of the Cultural Studies Association of Australia in December 2002.

2 And it can't be joked about. My newspaper this morning has a story about the British comedian Ali G offering to help the United States with 'some of the problems following 7/11', to which Tom Shales responded angrily in the Washington Post that 'nothing excuses joking about September 11': The Guardian, 24 February 2003, p. 2.

\section{References}

Baudrillard, Jean 1993, 'The Order of Simulacra', in Symbolic Exchange and Death, trans. Iain Hamilton Grant, Sage, London.

Blumenthal, Sidney 1986, The Rise of the Counter-establishment: From Conservative Ideology to Political Power, Times Books, New York.

Burke, Kenneth 1962 (1945), A Grammar of Motives, Meridian, Cleveland.

Chandler, James 1998, England in 1819: The Politics of Literary Culture and the Case of Romantic Historicism, University of Chicago Press, Chicago. 
Derrida, Jacques 1984, 'My Chances/Mes Chances: A Rendezvous with Some Epicurean Stereophanies', in Taking Chances: Derrida. Psychoanalysis, and Literature, Johns Hopkins University Press, Baltimore.

Fisk, Robert 2003, 'So He Thinks It's All Over ...', The Independent on Sunday, 4 May, p. 22. Gadamer, Hans-Georg 1998, Truth and Method, trans. Joel Weinsheimer and Donald G. Marshall, $2^{\text {nd }}$ edn, Continuum, New York.

Jencks, Charles 1987, The Language of Post-Modern Architecture, 5th edn, Rizzoli, New York. Jolles, André 1930, Einfache Formen, Wissenschaftliche Buchgesellschaft, Darmstadt.

Jonsen, Albert R. and Toulmin, Stephen 1988, The Abuse of Casuistry: A History of Moral Reasoning, University of California Press, Berkeley.

Kuhn, Thomas S. 1996 (1962), The Structure of Scientific Revolutions, $3^{\mathrm{n}} \mathrm{edn}$, University of Chicago Press, Chicago.

Laplanche, J. and Pontalis, J.B. 1973, The Language of Psycho-Analysis, trans. Donald NicholsonSmith, The Hogarth Press and the Institute of Psycho-Analysis, London.

Lukács, Georg 1969, 'Uber die Besonderheit als Kategorie der Asthetik', Probleme der Asthetik, Werke, vol. 10, Luchterhand, Neuwied, pp. 539-789.

Ragin, Charles C. and Becker, Howard S. 1992, What is a Case? Cambridge University Press, Cambridge.

Vidal, Gore 2002, 'The Enemy Within', The Observer, 'Review', 27 October, pp. 1-4.

Zizek, Slavoj n.d., 'Welcome to the Desert of the Real', hitp://web.mit.edu/cms/reconstructions/ interpretations/desertreal.html

John Frow teaches at the University of Edinburgh. He is the author most recently of Time and Commodity Culture and (with Tony Bennett and Mike Emmison) of Accounting for Tastes: Australian Everyday Cultures. 


\section{University Library}

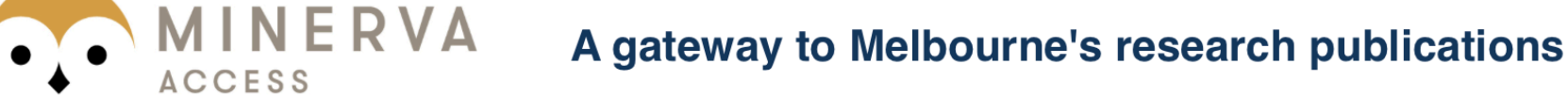

Minerva Access is the Institutional Repository of The University of Melbourne

Author/s:

FROW, J

Title:

The Uses of Terror and the Limits of Cultural Studies

Date:

2003

Citation:

FROW, J. (2003). The Uses of Terror and the Limits of Cultural Studies. Media International Australia incorporating Culture and Policy, 109 (November), pp.14-21

Persistent Link:

http://hdl.handle.net/11343/25743 